\title{
Dual Action of a Ligand for Eph Receptor Tyrosine Kinases on Specific Populations of Axons during the Development of Cortical Circuits
}

\author{
Valérie Castellani,, ${ }^{1}$ Yong Yue, ${ }^{2}$ Pan-Pan Gao, ${ }^{2}$ Renping Zhou, ${ }^{2}$ and Jürgen Bolz ${ }^{1}$ \\ 1/nstitut National de la Santé et de la Recherche Médicale Unité 371 "Cerveau et Vision," 69500 Bron, France, and \\ ¿Laboratory for Cancer Research, Department of Chemical Biology, College of Pharmacy, Rutgers University, Piscataway, \\ New Jersey 08855
}

The structural basis of cortical columns are radially oriented axon collaterals that form precise connections between distinct cortical layers. During development, these connections are highly specified from the initial outgrowth of collateral branches. Our previous work provided evidence for positional cues confined to individual layers that induce and/or prevent the formation of axon collaterals in specific populations of cortical neurons. Here we demonstrated with in situ hybridization techniques that mRNA of the Eph receptor tyrosine kinase EphA5 and one of its ligands, ephrin-A5, are present in distinct cortical layers, at a time when intrinsic connections are being formed in the cortex. Axonal guidance assays indicate that
ephrin-A5 is a repellent signal for a populations of axons that in vivo avoid the cortical layer expressing ephrin-A5. In contrast to its established role as a repulsive axonal guidance signal, ephrin-A5 specifically mediates sprouting of those cortical axons that target the ephrin-A5-expressing layer in vivo. These results identify a novel function of ephrin-A5 on axonal arbor formation. The laminar distribution and the dual action on specific populations of axons suggest that ephrin-A5 plays a role in the assembly of local cortical circuits.

Key words: wiring molecules; cortical development; cortical circuit formation; axonal guidance; axonal branching; ephrins; Eph receptors; in vitro assays
A prominent feature of the local circuitry in the mammalian cerebral cortex is the plexus of axon collaterals of cortical pyramidal and stellate cells. Radially oriented collaterals link cells between different cortical layers; these connections constitute the anatomical substrate for the columnar organization of the cortex (Lund and Boothe, 1975; Gilbert and Wiesel, 1979; Martin and Whitteridge, 1984). Tangentially oriented collaterals within cortical layers have a clustered distribution and interconnect columns with similar functional specificities (Ts'o et al., 1986; Gilbert and Wiesel, 1989; Schwarz and Bolz, 1991; Malach et al., 1993). During development, collateral clusters in the tangential domain emerge from an initially diffuse pattern by elimination of axonal branches in inappropriate regions and by selective growth in appropriate regions (for review, see Katz and Callaway, 1992). There is convincing evidence that patterns of neuronal activity are essential for the specification of the intralaminar clustering (Callaway and Katz, 1990; Luhmann et al., 1990; Löwel and Singer, 1992). In contrast, the elaboration of radially oriented interlaminar connections is specified from the initial stages of collateral sprouting (Lund et al., 1977; Meyer and Ferres-Torres, 1984; Katz, 1991; Callaway and Lieber, 1996). We found previously that membrane-associated molecules expressed in individual cortical laminae provide crucial information for the assembly of local cortical circuits. Some of these molecules act as attractive,

Received Dec. 1, 1997; revised March 23, 1998; accepted March 26, 1998.

This work was supported by the Human Frontiers Science Program (J.B.), National Institutes of Health Grant 1RO1NS36788-01 (R.Z.), and Institut Lilly (V.C.). We thank Naura Chounlamountri for excellent technical assistance.

Correspondence should be addressed to Jürgen Bolz, Institut National de la Santé et de la Recherche Médicale Unité 371 "Cerveau et Vision," 18 avenue du Doyen Lépine, 69500 Bron, France.

Copyright (C) 1998 Society for Neuroscience $\quad 0270-6474 / 98 / 184663-10 \$ 05.00 / 0$ others as repulsive signals that regulate collateral formation and guide growing axons within the different cortical layers (Castellani and Bolz, 1997).

So far very little is known about the molecular nature of the signals that influence the growth, targeting, and arbor formation of cortical axons. Over the past years, two gene families, the netrins and semaphorins, have been identified that encode diffusible proteins involved in long-range axonal guidance in spinal cord, hindbrain, and midbrain (Luo et al., 1993; Kennedy et al., 1994; Serafini et al., 1994; Messersmith et al., 1995; Püschel et al., 1995). However, molecules involved in the formation of layerspecific cortical circuits must have precise local effects acting only on segments of cortical axons. Recent work led to the identity of a family of membrane-bound proteins, the ephrins (Eph Nomenclature Committee, 1997), which are ligands for Eph receptor tyrosine kinases. Ephrins have repellent axonal guidance activities and define inhibitory territories for axonal innervation (Cheng et al., 1995; Drescher et al., 1995; Gao et al., 1996; Nakamoto et al., 1996; Zhang et al., 1996), and they are therefore candidate molecules for the specification of local cortical connections. To test this hypothesis, we first used in situ hybridization techniques to examine the distribution of ephrin-A5 and its receptor, Eph A5, in the developing cerebral cortex. Results show that at the developmental stages when local connections are being formed, ephrin-A5 and EphA5 exhibit discrete and complementary laminar expression patterns. We then performed in vitro experiments and found that ephrin-A5 exerts differential effects on the growth, guidance, and branch formation of distinct populations of cortical axons. Taken together, these findings suggest a role for ephrin-A5 in the construction of layer-specific cortical circuits. 


\section{MATERIALS AND METHODS}

In situ hybridization. In situ hybridization was performed as described in Zhang et al. (1997). Briefly, slide-mounted cryosections (12 $\mu \mathrm{m})$ were warmed quickly to room temperature and fixed in $4 \%$ paraformaldehyde in $0.1 \mathrm{M}$ phosphate buffer, $\mathrm{pH}$ 7.2. To hybridize with riboprobes, the sections were treated with proteinase $\mathrm{K}(40 \mathrm{ng} / \mathrm{ml})$, fixed again with $4 \%$ paraformaldehyde, immersed in triethanolamine $(50 \mathrm{~mm})$ in acetic anhydride solutions $(100 \mathrm{~mm})$ for $10 \mathrm{~min}$, and dehydrated. Sections were hybridized with the respective riboprobe $\left(2.5 \times 10^{6} \mathrm{cpm} / \mathrm{ml}\right)$ under stringent conditions $(50 \%$ formamide, $10 \%$ dextran sulfate, $1 \times$ Denhardt's solution, $0.2 \mathrm{mg} / \mathrm{ml}$ herring sperm DNA, and $10 \mathrm{~mm}$ dithiothreitol) for $18-24 \mathrm{hr}$ at $55^{\circ} \mathrm{C}$. After hybridization, sections were washed in $5 \times \mathrm{SSC}$ (saline-sodium citrate) at $65^{\circ} \mathrm{C}$ for $20 \mathrm{~min}$, followed by $50 \%$ formamide in $2 \times \mathrm{SSC}$ for $30 \mathrm{~min}$ at the same temperature. The sections were washed twice in RNase buffer (10 mM Tris-HCl, pH 7.5, $0.5 \mathrm{M}$ $\mathrm{NaCl}$, and $5 \mathrm{~mm}$ EDTA) for $20 \mathrm{~min}$ each and incubated for $30 \mathrm{~min}$ at $37^{\circ} \mathrm{C}$ in the same buffer containing $20 \mu \mathrm{g} / \mathrm{ml}$ RNase A. Sections were rinsed in the RNase buffer for $20 \mathrm{~min}$ at $37^{\circ} \mathrm{C}$. Finally, the sections were washed in $50 \%$ formamide, $2 \times \mathrm{SSC}$ at $65^{\circ} \mathrm{C}$ for $30 \mathrm{~min}$, and $2 \times \mathrm{SSC}$ and $0.1 \times \mathrm{SSC}$ at room temperature for $15 \mathrm{~min}$, respectively. After washes, the sections were dehydrated and exposed to x-ray film for 3-6 d. After film development, the sections were coated with Kodak NTB-2 photographic emulsion diluted 1:1 with distilled water. The sections were exposed for 2-3 weeks at $4^{\circ} \mathrm{C}$, developed, and counterstained with thionin.

EphA5 was detected with a 373 bp antisense riboprobe corresponding to nucleotide position 1445-1818 (Zhou et al., 1994). Ephrin-A5 was detected using a 700 bp human ephrin-A5 antisense riboprobe including the full coding region. The riboprobes were synthesized with T7 or T3 RNA polymerase after digestion with an appropriate restriction enzyme. The sense riboprobes were used as controls.

Construction of ephrin-A5-expressing cell line. The full-length human ephrin-A5 was cloned into a retroviral vector $\mathrm{pLIG}^{*}$, which contains a $\beta$-galactosidase gene fused with an aminoglycoside phosphotransferase for G418 resistance (Lillian, 1996). The construct was then transfected into NIH3T3 cells. G418 resistant colonies were selected and screened for ephrin-A5 expression using EphA5-AP binding as described (Gao et al., 1996). Control cell lines were similarly constructed with the expression vector containing no insert. EphA5-AP binds strongly to ephrin-A5expressing NIH3T3 cells (Elf-1-3T3). In contrast, no significant staining was observed in parental or vector-transfected NIH3T3 cells.

Preparation of cortical explants. Cortices from embryonic day (E) 15 and $\mathrm{E} 16$ rat embryos (E1, first day of gestation) were dissected under a microscope with oblique illumination and cut into $200 \times 200 \times 200 \mu \mathrm{m}$ cubes with a McIIwain tissue chopper. At this early developmental stage, the cortical plate is composed of subplate neurons, the earliest cells produced, and layer 6 neurons. Postmitotic neurons generated in the proliferative zone are also predominantly destined for layer 6 (Miller, 1988; Bayer and Altman, 1991). According to the sequential production of cortical neurons from the deep to the superficial layers, at later developmental stages deep layer cells have migrated out to the ventricular zone. Therefore, to isolate cortical neurons destined for the superficial layers, we prepared the ventricular zone toward the end of neurogenesis. For this, cortices from E19 rat embryos were dissected and cut into $200-\mu \mathrm{m}$-thick slices. The ventricular zone was then isolated from individual slices by cutting along the laminar border between the intermediate zone and the subventricular zone. Under the operating microscope, the ventricular zone appears as a bright tissue densely packed with cells, whereas the adjacent intermediate zone is more transparent and cell density is much lower. To prepare explants, the slices of isolated ventricular zone were then cut into small cubes. As a control, intact and dissected slices were cut into $20-\mu \mathrm{m}$-thick sections and subsequently stained with bisbenzimide. Microscopic examination of these slices confirmed that the landmarks used for the dissection corresponded to the ventricular zone.

Preparation of membrane substrates. Postnatal day (P) 5 cortex was dissected and collected in a homogenization buffer, as described in Walter et al. (1987). In some experiments, layers 6 and 1-4 were isolated from P8 rat cortex, as described in Castellani and Bolz (1997). The optical densities (ODs) of the membrane suspensions were measured with a spectrophotometer at $220 \mathrm{~nm}$. OD was adjusted to 0.1 after 15 -fold dilution in $2 \%$ SDS. NIH3T3 cells transfected with an ephrin-A5 expression plasmid or with the vector alone (control cells) were grown to confluence in DMEM/F12 culture medium supplemented with fetal bovine serum $(10 \%)$. Membranes from the cells were purified using the following procedure. The culture medium was removed from the Petri dishes and replaced by $1 \mathrm{ml}$ of homogenization buffer. Cultures were then cooled on dry ice for 1 min to disrupt the cell membranes. Tissues were scrapped and collected, and membranes were purified as described previously (Götz et al., 1992). In some experiments, the cell and cortical membranes were incubated with phosphatidylinositol phospholipase C (PI-PLC) (3 U/5 mg proteins) for $2 \mathrm{hr}$ at $37^{\circ} \mathrm{C}$.

To prepare uniform membrane carpets, pairs of sterile glass coverslips were first incubated as a sandwich with $100 \mu$ l of Gey's balanced salt solution containing $1.5 \mu \mathrm{g}$ of laminin and $0.5 \mu \mathrm{g}$ of poly-L-lysine for $2 \mathrm{hr}$ at $37^{\circ} \mathrm{C}$. These laminin-poly-L-lysine-coated coverslips were then washed with PBS and incubated again in sandwich with $100 \mu$ l of membrane suspension for $3 \mathrm{hr}$ at $37^{\circ} \mathrm{C}$. After separation, the coverslips were placed in a Petriperm dish and recovered with $750 \mu \mathrm{l}$ of culture medium. Substrates composed of alternating membrane stripes were prepared as described in Walter et al. (1987). Tissues were explanted on the coverslips, and culture medium was adjusted to $2 \mathrm{ml}$. Cultures were kept for $2 \mathrm{~d}$ at $37^{\circ} \mathrm{C}$ under $5 \% \mathrm{CO}_{2}$ in air atmosphere and then fixed with paraformaldehyde $4 \%$ and $3 \%$ sucrose for observation. In some experiments, purified ephrin-A5 $(2 \mu \mathrm{g} / \mathrm{ml})$ was applied to the culture medium.

Analysis of axonal growth, branching, and guidance. To confirm the neuronal origin of the processes extending from the explants, immunostaining was performed with the axon-specific marker antibody SMI31 (Sternberger and Meyer Inc.). Axons extending from the explants were counted using a $20 \times$ phase contrast objective [Zeiss Plan-Neofluar, numerical aperture (NA) 0.50]. In this analysis, all explants were scored, including those that exhibited no growth. To estimate axonal elongation, 10 explants per coverslip were randomly selected, and the six longest fibers were measured. The Student's $t$ test was used for statistic comparison. To quantify axonal branching, explants were examined at higher magnification using a $40 \times$ phase contrast objective (Zeiss Plan-Neofluar, NA 0.75$)$ in combination with additional magnification lenses (1.6X Optovar). Close to the explants, axonal density is very high and axons often form tight bundles, whereas farther away from the explants most fibers defasciculate and axonal density becomes lower as they extend over a larger area. Therefore, beginning with the growth cone, a 100- to $200-\mu \mathrm{m}$-long distal segment of individual axons was analyzed. Approximately five axons per explant were examined; crossing fibers and fascicles were excluded. The number of side branches was counted, and the length of each axonal segment was measured. Axonal branching was defined as the ratio between the total number of axonal branches and the total segment length. Axonal branching under control condition was normalized to $100 \%$. For comparison of different experimental conditions, statistical analysis was performed with a permutation test. In the stripe assays, axons growing in each set of membrane lanes were counted as described in Castellani and Bolz (1997). Data are presented in percentage, and Student's $t$ test was used for statistical analysis.

\section{RESULTS}

\section{EphA5 and ephrin-A5 expression patterns in the developing cerebral cortex}

In the developing mammalian cerebral cortex, neurons destined for one layer are generated at approximately the same time in the ventricular zone and then migrate toward the pia. Cells in the deep cortical layers are produced before those in the superficial layers; cortical laminae are therefore formed inside-out (Angevine and Sidman, 1961; Berry and Eayrs, 1963; Berry and Rogers, 1965; Rakic, 1972; Luskin and Shatz, 1985). In rodents, the final cortical lamination is established at approximately $6 \mathrm{~d}$ after birth, when cells of the most superficial layers have arrived at their final position (Miller and Peters, 1981; Bayer and Altman, 1991; Kageyama and Robertson, 1993). It has been reported that some migrating neurons already emit efferent axons growing out of the cortex (Shoukimas and Hinds, 1978; Schwartz et al., 1991; Auladell et al., 1995). The formation of the plexus of intracortical axon collaterals, however, is initiated only after neurons have settled in their final laminar position (Katz, 1991; Callaway and Lieber, 1996). To examine whether Eph receptor tyrosine kinases and their ligands are present during these developmental stages, we first performed in situ hybridization in mouse cerebral cortex at P7. Analysis of EphA5 and ephrin-A5 mRNA revealed a 


\section{EphA5}

E16
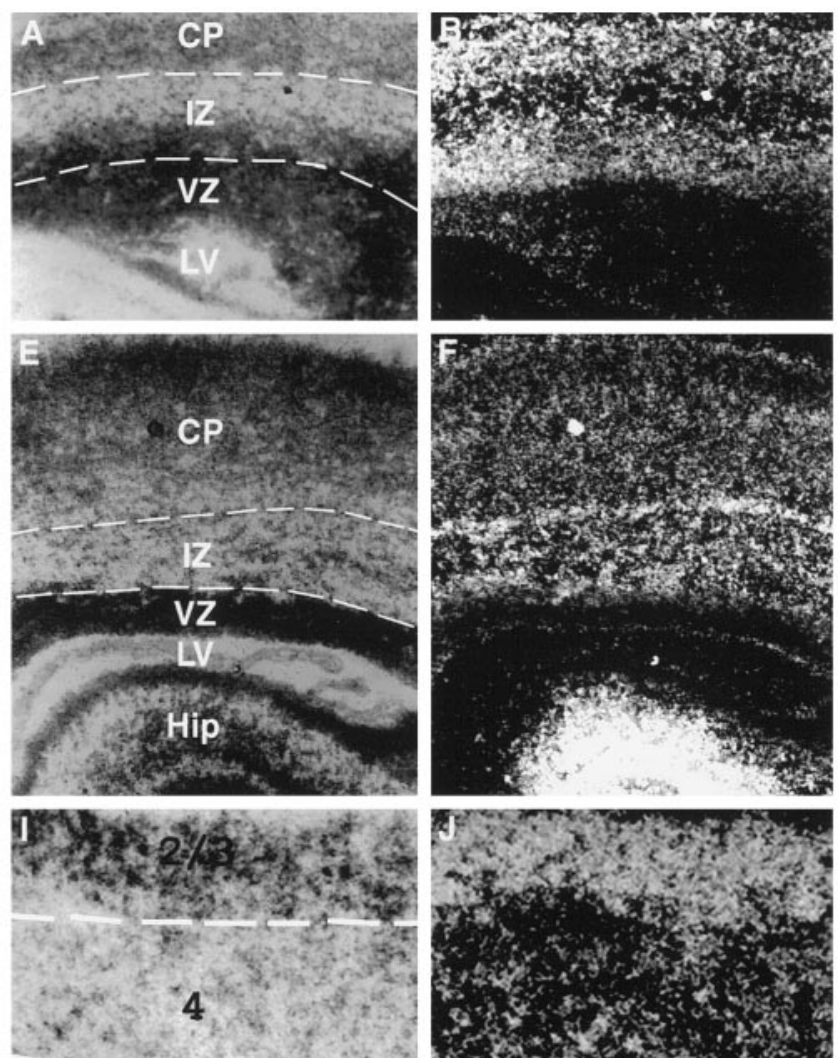

P7
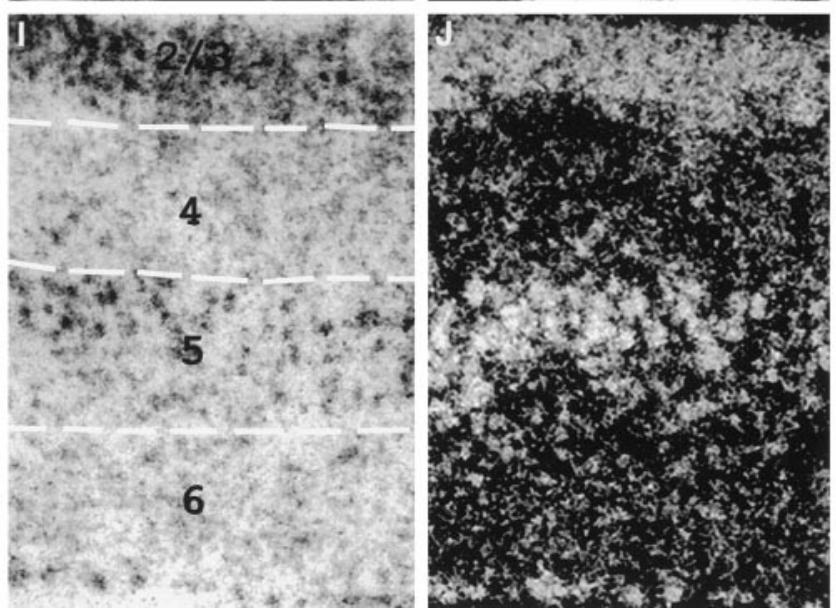
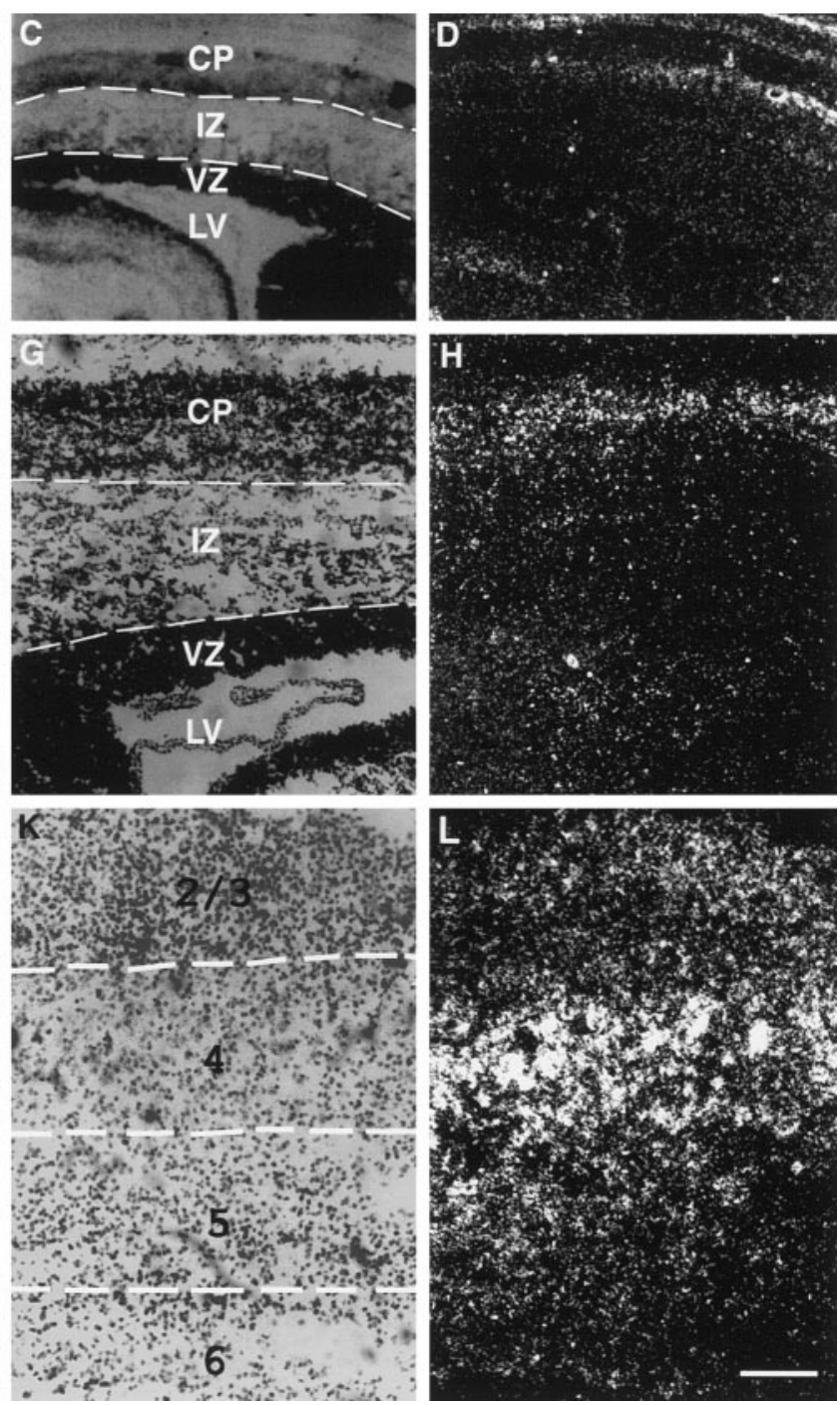

Figure 1. Layer-specific expression of EphA5 and ephrin-A5 in the developing mouse cerebral cortex. $A, B, E, F, I, J$, Bright- and dark-field microphotographs of coronal sections of sensorimotor cortex hybridized to EphA5 antisense riboprobe. $A, B$, At E16, strong levels of mRNA expression are detected in the cortical plate and the subventricular zone. $E, F$, At E18, hybridization signals are located in the intermediate zone and in the cortical plate. $I, J$, At P7, EphA5 mRNA is selectively detected in layers $2 / 3,5$, and $6 \mathrm{~b} . C, D, G, H, K, L$, Bright- and dark-field microphotographs of the same regions hybridized to ephrin-A5 antisense riboprobe. $C$, $D$, At E16, a weak labeling is detected at the top of the cortical plate. $G$, $H$, At E18, the hybridization signal increases. It is still located in the same region and to a lesser extent throughout the cortical thickness. $K, L, A t P 7$, high levels of ephrin-A5 mRNA expression are detected in layer 4. Thionin stainings show the different layers. $C P$, Cortical plate; $I M Z$, intermediate zone; $V Z$, ventricular zone; $L V$, lateral ventricle; Hip, hippocampus; $1-6$, cortical layers.

consistent level of hybridization in discrete cortical layers. As illustrated in Figure 1I,J, Eph-A5 mRNA was selectively detected in layers $2 / 3,5$, and 6 b, with very little labeling in layers 4 and 6 . In contrast, ephrin-A5 riboprobes exhibited a weak staining throughout the cortical thickness, but a strong hybridization signal was obtained only in layer 4 (Fig. $1 K, L$ ).

To examine the developmental expression patterns of EphA5 and ephrin-A5, we also performed in situ hybridization at different prenatal stages. Already at E13, EphA5 mRNA was detected in the cortical plate, with very low levels of expression in the ventricular zone (data not shown). At E16, EphA5 mRNA could also be found in the intermediate zone (Fig. $1 A, B$ ). At this stage, precursor cells in the ventricular zone produce neurons destined for layers 2/3 (Miller, 1988; Bayer and Altman, 1991). At E18, when most of the layers $2 / 3$ neurons have already migrated out of the neuroepithelium, EphA5 mRNA was detected in the intermediate zone. The labeling in the cortical plate and subplate remains unchanged (Fig. $1 E, F)$. In contrast to EphA5, there was no labeling with ephrin-A5 riboprobes at E13. A weak labeling with ephrin-A5 riboprobes was first detectable at E16 in the most superficial portion of the cortical plate (Fig. 1C,D). At E18, the intensity of this labeling increased, and there was additional staining of cells scattered throughout the intermediate zone (Fig. $1 G, H)$.

\section{Functional assays}

The postnatal expression patterns of ephrin-A5 and EphA5 in distinct cortical layers imply that they are important components 


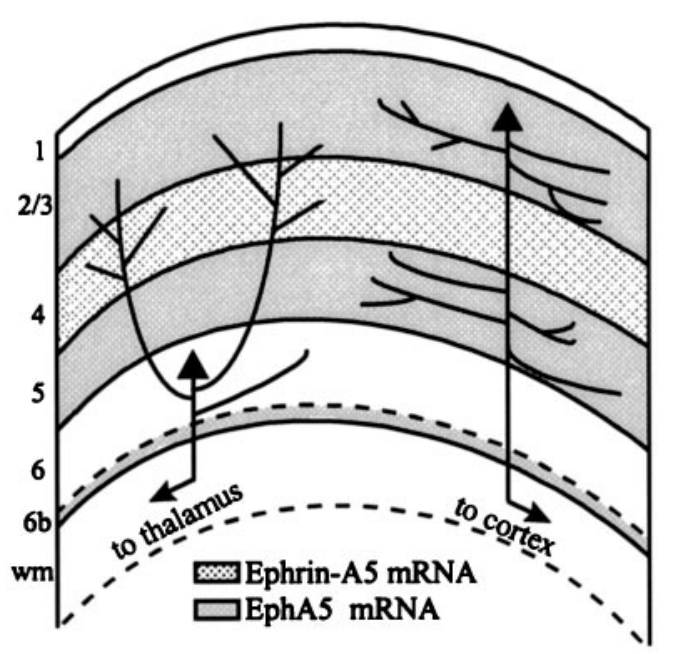

Figure 2. Schematic drawing of intrinsic axon collateral projections established by pyramidal neurons of layers 6 and 2/3. EphA5 mRNA expression is indicated by dark shading; ephrin-A5 mRNA is indicated by dots. Layers 2/3 express EphA5 receptors, and their axons avoid ephrin-A5 expressing layer 4. In contrast, layer 6 neurons do not express the receptor, and their axons branch in layer 4 where the ligand is detected.

of the laminar specificity of local cortical circuits. As illustrated schematically in Figure 2, axons of layers 2/3 neurons possess abundant collaterals, both in the superficial layers and in layer 5 . These axon collaterals can run for many millimeters in these layers without crossing into the intervening layer 4 (Fisken et al., 1975; Rockland et al., 1982; Gilbert and Wiesel, 1983; Burkhalter, 1989; Callaway and Katz, 1990; Fitzpatrick, 1996), where ephrin-A5 is expressed. On the other hand, layer 6 cells emit many axon collaterals that ascend through layer 5 and then branch extensively in layer 4. Previous work suggested that ephrin-A5 acts as a repulsive signal for specific axonal populations, preventing fiber elongation and possibly axonal branching in regions where this ligand is expressed (Cheng et al., 1995; Drescher et al., 1995; Zhang et al., 1996). Because EphA5, the receptor for ephrin-A5, is present in layers $2 / 3$ and because ephrin-A5 is expressed in those cortical layers that are not targeted by layers $2 / 3$ neurons, one might expect that ephrin-A5 acts as a repulsive axonal guidance signal for this class of cortical neurons. In contrast, because layer 6 neurons do not express the EphA5 receptor, they might be able to grow and branch in ephrin-A5-containing layers because they do not respond to this repulsive signal.

To test this hypothesis, we studied the effects of ephrin-A5 on axonal growth and branching of cortical neurons, destined for either layers $2 / 3$ or 6 . Explants from each population of neurons were cultured on membrane substrates from NIH3T3 cells transfected with an ephrin-A5 expression plasmid or transfected with the vector alone (control substrate). In a first set of experiments, we examined axonal outgrowth on membranes derived from vector-transfected NIH3T3 cells. Layer 6 explants emitted numerous long axons on this substrate; the average $L_{50}$ value (length exceeded by $50 \%$ of all axons; see Materials and Methods) was $388 \mu \mathrm{m}$. In contrast, layers $2 / 3$ explants emitted only half as many axons as layer 6 explants and the $L_{50}$ value for this population of axons was only $192 \mu \mathrm{m}$ (Table 1). To improve axonal outgrowth, we added membranes from early postnatal cortex to NIH3T3 cell membranes, because these membranes contain growth-promoting molecules for cortical neurons (Götz et al., 1992). Several con- centrations were tested to determine adequate culture conditions for both populations of cortical neurons. As indicated in Table 1, the addition of postnatal cortical membranes greatly enhanced axonal growth of layers $2 / 3$ cells in a dose-dependent manner, whereas the effects on layer 6 cells were less pronounced. In the experiments described below, for layers $2 / 3$ explants, 25 or $33 \%$ cortical membranes were added to the membranes from NIH3T3 cells. Layer 6 explants either were grown on pure membranes from NIH3T3 cells or $25 \%$ cortical membranes were added.

\section{Differential effects of ephrin-A5 on axonal growth of cortical neurons}

To examine the influence of ephrin-A5 on axonal growth, cortical explants were cultured for $2 \mathrm{~d}$ on uniform membrane substrates from ephrin-A5-transfected or vector-transfected NIH3T3 cells. For layers $2 / 3$ explants, there was a reduction by $\sim 40 \%$ in axonal outgrowth on ephrin-A5-containing membranes compared with control membranes (254 explants examined; $p<0.001$ ) (Figs. $3 A, B, 4 A$; Table 2). In addition, on control membranes $50 \%$ of the layers $2 / 3$ axons were longer than $250 \mu \mathrm{m}$, whereas on ephrin-A5containing membranes only $20 \%$ of these axons reached this length (360 axons examined; $p<0.0001$ ) (Fig. $4 C$, Table 2). In contrast to layers $2 / 3$ axons, the number and the length of axons extending from layer 6 explants were not influenced by the presence of ephrin-A5. As depicted in Figure $4 A$, the average number of axons per explant on membranes from vectortransfected NIH3T3 was 23.8, and on membranes from ephrinA5-transfected NIH3T3 it was 21.7 (245 explants examined). Likewise, when cortical membranes were added to the cell membranes, the mean outgrowth per explant was 30.3 axons per explant on ephrin-containing membranes and 28.8 axons per explant on control membranes (248 explants examined) (Table 2). In both cases there was no significant difference in axonal length from layer 6 explants on membranes with or without ephrin-A5 (total of 750 axons examined; $p>0.1$ ) (Fig. 4D, Table 2).

Because ephrin-A5 is a glycosyl phosphatidylinositol (GPI)anchored ligand, one would expect that the effects observed with layers $2 / 3$ axons are abolished by treatment of the membranes with PI-PLC, an enzyme that specifically cleaves GPI-linked molecules. Therefore, we repeated the experiments with PI-PLCincubated ephrin-A5-transfected and vector-transfected membranes. As indicated in Figure 4B, PI-PLC treatment of ephrinA5-containing membranes almost completely restored axonal outgrowth; there was no longer a significant difference compared with control membranes (192 explants examined; $p<0.119$ ). Treatment of vector-transfected cells had no effect on axonal outgrowth (Fig. 4B). The effects of PI-PLC treatment on axonal length were relatively weak. Although PI-PLC incubation of ephrin-A5-containing membranes increased the $L_{50}$ value by 25 $\mu \mathrm{m}$, the axons were still shorter $(265 \mu \mathrm{m})$ than on control membranes (300 $\mu \mathrm{m}$; total of 94 axons; $p<0.031)$. One possible explanation is that axonal growth rate is very sensitive to ephrin-A5 and that higher concentrations of the enzymes are required to completely remove ephrin-A5 from the cell membranes.

\section{Ephrin-A5 is a repulsive guidance cue for layers 2/3 axons}

To examine the ability of ephrin-A5 to guide growing cortical axons, we cultured cortical explants on alternating stripes of control and ephrin-A5-containing membranes. When they grew 


\begin{tabular}{|c|c|c|c|c|}
\hline$\%$ Postnatal membranes & $0 \%$ & $25 \%$ & $33 \%$ & $50 \%$ \\
\hline \multicolumn{5}{|l|}{ Layers $2 / 3$ neurons } \\
\hline Axons per explant & $20.4 \pm 2.7, n=17$ & $38.6 \pm 3.3, n=21$ & $41.7 \pm 3.0, n=18$ & $42.3 \pm 2.8, n=22$ \\
\hline$L_{50}, \mu \mathrm{m}$ & $192, n=60$ & $310, n=60$ & $280, n=60$ & $370, n=60$ \\
\hline \multicolumn{5}{|l|}{ Layer 6 neurons } \\
\hline Axons per explant & $38.21 \pm 2.2, n=33$ & $41.2 \pm 2.4, n=37$ & $45 \pm 1.7, n=47$ & $42.5 \pm 2.4, n=42$ \\
\hline$L_{50}, \mu \mathrm{m}$ & $380, n=60$ & $390, n=60$ & $410, n=60$ & $420, n=60$ \\
\hline
\end{tabular}

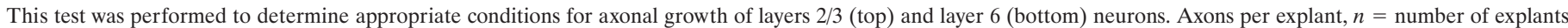
examined; $L_{50}$ (length exceeded by $50 \%$ of the axons), $n=$ number of axons measured.
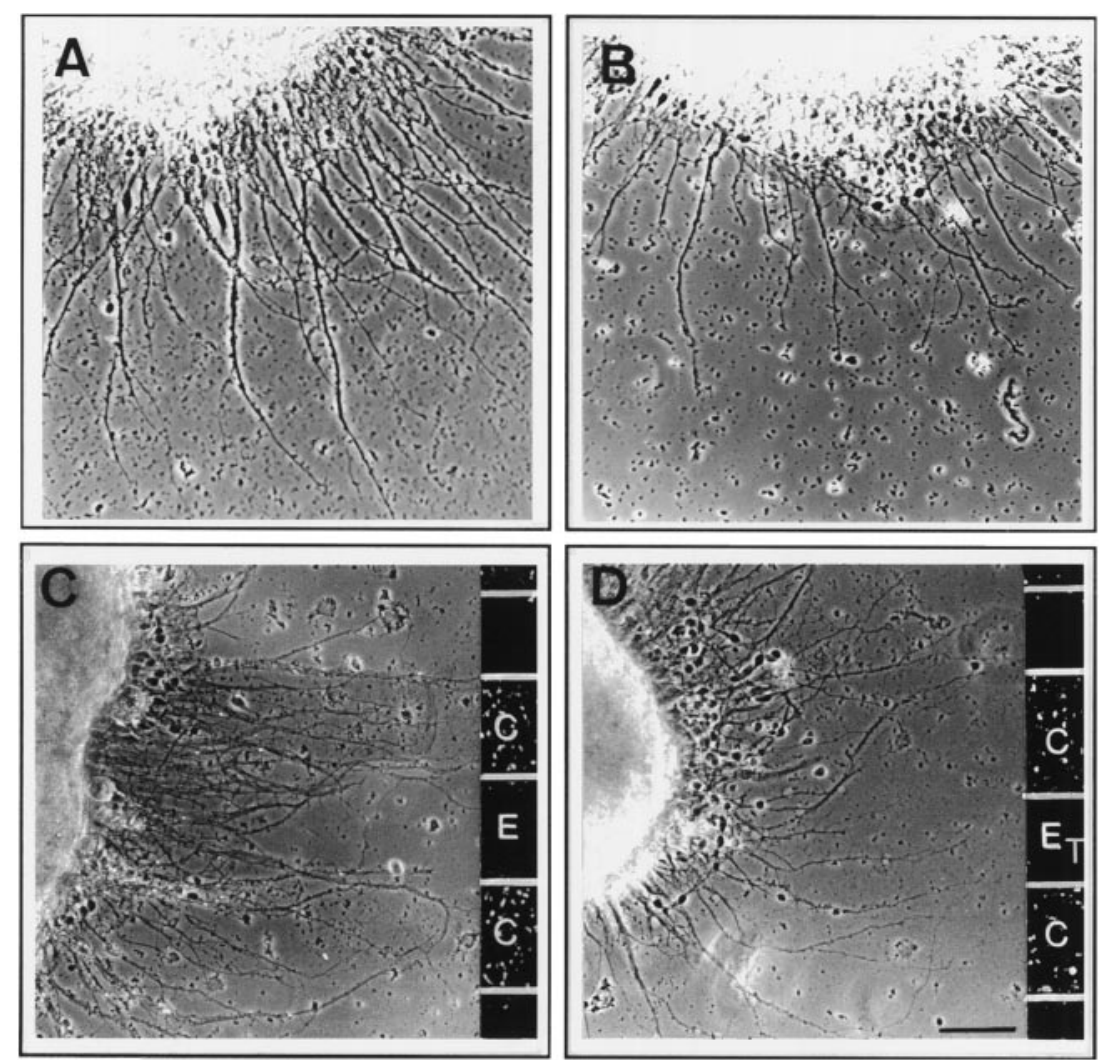

Figure 3. $A, B$, Phase-contrast photomicrographs of layers $2 / 3$ explants cultured on control substrates $(A)$ and ephrin-A5 substrates $(B)$. Both fiber outgrowth and axonal length are reduced in the presence of ephrin-A5. $C$, $D$, Layers $2 / 3$ axons extending on alternative membrane lanes prepared from ephrin-A5 and control cells. $C, \mathrm{Ax}-$ ons avoid the lanes with ephrin-A5 and grow on the control lanes. Note that the axons form fascicles on ephrin-A5 membrane lanes. $D$, Ephrin-A5 membranes are treated with PI-PLC, and axons of layers $2 / 3$ neurons are no longer guided by the membrane stripes. $E$, Ephrin-A5 cell membranes; $E_{T}$, treated with PI-PLC; $C$, control cell membranes. Scale bar, $50 \mu \mathrm{m}$.

parallel to the membrane stripes, axons of layers $2 / 3$ neurons formed sharp bundles and clearly avoided the membrane stripes with ephrin-A5 (Fig. 3C). On the substrates diluted with $25 \%$ cortical membranes, $66 \%$ of the axons preferred to grow on the lanes with control membranes (75 explants examined; $p<0.0001$ ) (Fig. 5A); on substrates diluted with $33 \%$ cortical membranes, $70 \%$ grew preferentially on control membranes (110 explants examined; $p<0.0001)$. This preference was abolished after treatment with PI-PLC (49\% and 51\% of fibers grew in control and ephrin-A5 membrane stripes, respectively; 104 explants examined; $p<0.37$ ) (Figs. $3 D, 5 B)$. Axons extending perpendicular to the membrane stripes were able to grow across stripe borders. However, as they crossed ephrin-A5-containing membrane stripes, they often formed tight axonal bundles and defasciculated again when they crossed control membrane stripes. In contrast to layers $2 / 3$ axons, fibers extending from layer 6 explants exhibited no preference for any of the substrates. In 80 explants examined, $52 \%$ of the fibers were growing in the stripes with control membranes, and $48 \%$ were growing in the stripes with ephrin-A5 membranes $(p>0.83)$ (Fig. $5 A)$.

\section{Ephrin-A5 selectively promotes axonal sprouting of layer 6 neurons}

Because ephrin-A5 is expressed in those cortical layers where layers $2 / 3$ neurons avoid forming axonal arbors, ephrin-A5 could act as an inhibitor of collateral formation for this set of axons. To examine this possibility, individual axons extending from the explants were examined at high magnification, and side branches were counted under various conditions. An analysis of 275 layers $2 / 3$ axons revealed, however, that the branch frequency was not influenced by the presence of ephrin-A5 in the membrane substrate $(p>0.29)$ (Fig. $5 C$, Table 2$)$. The lack of effect could be attributable to the presence of postnatal cortical membranes in the substrates, on which axonal branching of layers $2 / 3$ neurons is high (data not shown). To examine this issue, we diluted cell membranes with cortical membranes prepared from a nontarget layer on which axonal branching was previously found to be reduced (Castellani and Bolz, 1997). As expected, axonal branching was reduced on the control substrates (from 100 on membranes diluted with cortical membranes from all layers to 54 on 
Figure 4. Quantitative analysis of axonal growth on membranes prepared from ephrin-A5-expressing cells and control cells. For layer 6 neurons, the substrate was composed of pure cell membranes and for layers $2 / 3$ neurons, $25 \%$ of postnatal cortical membranes were added to the cell membranes. Filled bars correspond to ephrin-A5 substrates and open bars to control substrates. $A$, Number of axons per explant. Outgrowth of layers $2 / 3$ neurons is selectively reduced on ephrin-A5 substrates, whereas there is no difference in axonal growth of layer 6 neurons on ephrin-A5 and control substrates. $B$, Number of axons extending per explant after incubation of the cell membranes with PI-PLC. There is no longer a difference in the outgrowth of layers $2 / 3$ neurons on ephrin-A5 and control substrates. $C, D$, Analysis of axonal length. The plot depicts the distribution of axonal length; values given on the $y$-axis indicate the proportion of axons that reached the length shown on the $x$-axis. Filled circles represent ephrin-A5 substrate; open circles represent control substrate. A significant decrease in axonal length is observed for layers $2 / 3$ neurons, but not for layer 6 neurons. n.s., Not significant. Error bars indicate SEM.
A
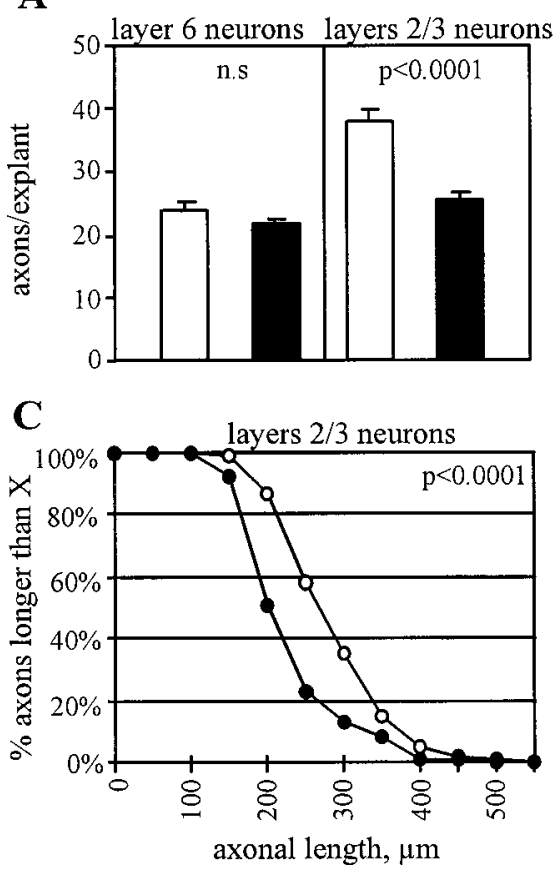

B

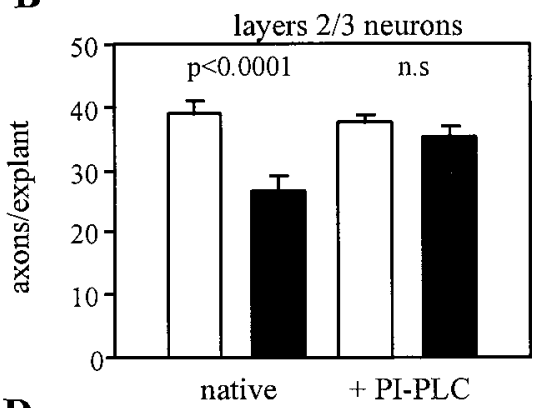

D

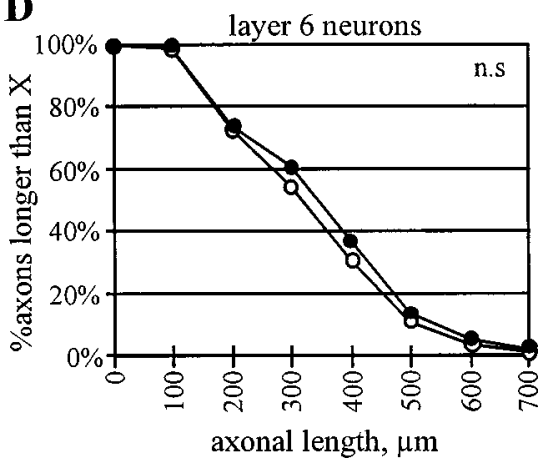

Table 2. Axonal outgrowth, axonal length, and axonal branching on membranes from NIH3T3 cells diluted with 25\% of postnatal cortical membranes for layer 6 neurons and $33 \%$ for layers $2 / 3$ neurons

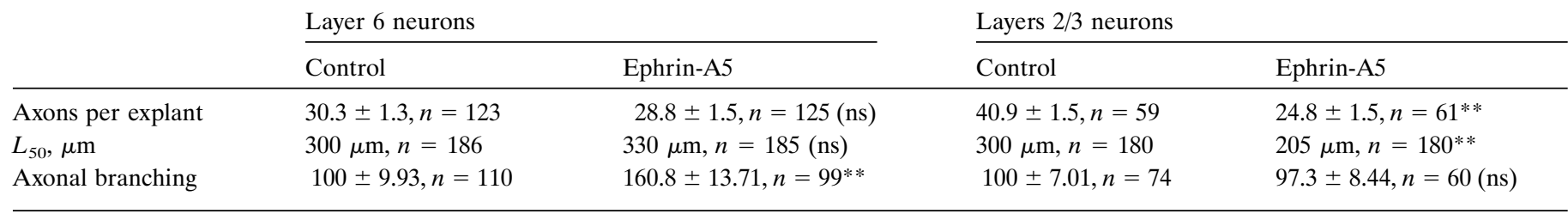

Axonal branching was normalized to 100 .

${ }^{*} p<0.05,{ }^{* *} p<0.0001 ;$ ns, not significant. Same convention as in Table 1.

membranes diluted with cortical membranes from the nontarget layer 6). However, in presence of ephrin-A5, axonal branching remained unchanged (49.3; total of 47 axons examined; $p>0.52$ ). Thus, for layers $2 / 3$ neurons, ephrin-A5 is a repellent guidance factor and inhibits axonal extension, but it does not influence branch formation of this class of axons.

We also examined the branch formation of layer 6 neurons in the presence and absence of ephrin-A5. Thus far, all of the functions attributed to ephrins on the formation of neuronal connections can be explained by their ability to act as repulsive signals for growing axons. It was therefore surprising to find that ephrin-A5 strongly promoted axonal branching of layer 6 neurons (Fig. 6). In a total of 225 layer 6 axons examined, branch frequency on ephrin-A5-transfected NIH3T3 membranes was almost twice as high as on control membranes (98\% increase; $p<$ 0.0001) (Fig. 5C). The effect was less pronounced when postnatal cortical membranes were added to the cell membranes $(61 \%$ increase; 209 axons examined; $p<0.001$ ) (Table 2). One possible explanation could be that the effect of ephrin-A5 was diluted by the presence of branch-promoting molecules in postnatal cortical membranes. In accordance with this idea, axonal branching of layer 6 neurons on postnatal cortical membranes alone was 3.5 times higher than on membranes from control NIH3T3 cells (93 axons examined on cortical membrane substrates). To verify that the branch-promoting effect on membrane substrates from trans- fected NIH3T3 cells was attributable to the presence of ephrinA5, in a separate set of experiments axonal branching was measured on membrane substrates incubated with PI-PLC. Under these conditions, there was no longer a difference in axonal branching between ephrin-A5 and control substrates (308 axons examined; $p>0.40$ ) (Fig. 5D).

The branching effect on membranes from ephrin-A5transfected cells could result from indirect interactions between the explants and the membranes from NIH3T3 cells. Previous work demonstrated that soluble ephrins bind, but do not activate, Eph receptors (Davis et al., 1994). Moreover, when dissociated cortical neurons were cultured on ephrin-A5-expressing astrocytes, soluble ephrin-A5 prevents axon bundling (Winslow et al., 1995). We therefore examined whether similar antagonist effects of soluble ephrin-A5 could be observed on axonal sprouting of layer 6 neurons. In these experiments, cortical explants were cultured on membranes from control and ephrin-A5-transfected cells, with purified ephrin-A5 applied to the culture medium. We observed that axonal branching on ephrin-A5 membranes decreased by $64 \%$, compared with the control (total of 75 axons examined; $p<0.05$ ) (Table 3). Moreover, when the explants were cultured on control cell membranes, application of soluble ephrin-A5 had no effect on axonal branching (total of 59 axons examined; $p>0.49$ ) (Table 3).

Our in situ hybridization data suggest that ephrin-A5 is ex- 
A

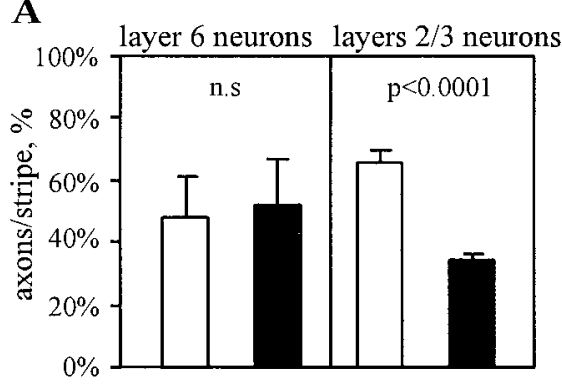

B

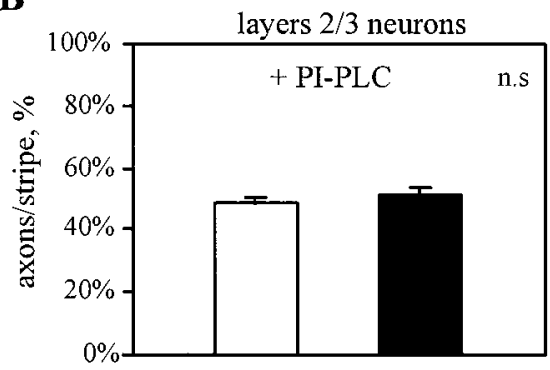

C

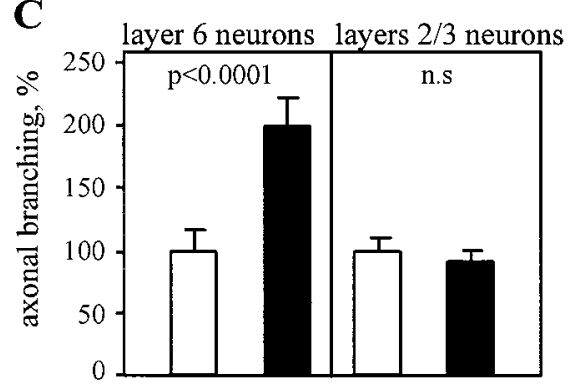

D

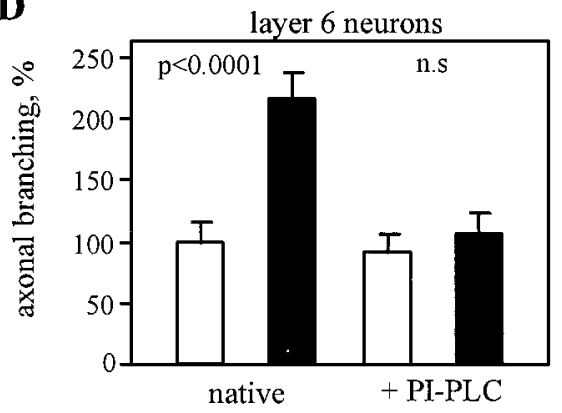

Figure 5. Quantitative analysis of axonal guidance and branch formation. $A$, Axons extended on alternating ephrin-A5 and control membrane lanes. Bars represent the percentage of axons on each set of lanes. Axons of layers $2 / 3$ neurons avoid membrane lanes containing ephrin-A5 and grow preferentially in the control membrane lanes. Axons of layer 6 neurons grow in both sets of membrane stripes. $B$, Treatment of membranes from ephrin-A5expressing cells with PI-PLC abolishes the guidance of layers $2 / 3$ axons. $C$, Axonal branching increases for layer 6 neurons on ephrin-A5 substrates, whereas for layers $2 / 3$ neurons there is no effect. $D$, PI-PLC treatment of the cell membranes. The axonal branch density of layer 6 neurons remains comparable on the control substrates, whereas it decreases to the control value on the ephrin-A5-treated substrate. n.s., Not significant. Error bars indicate SEM.

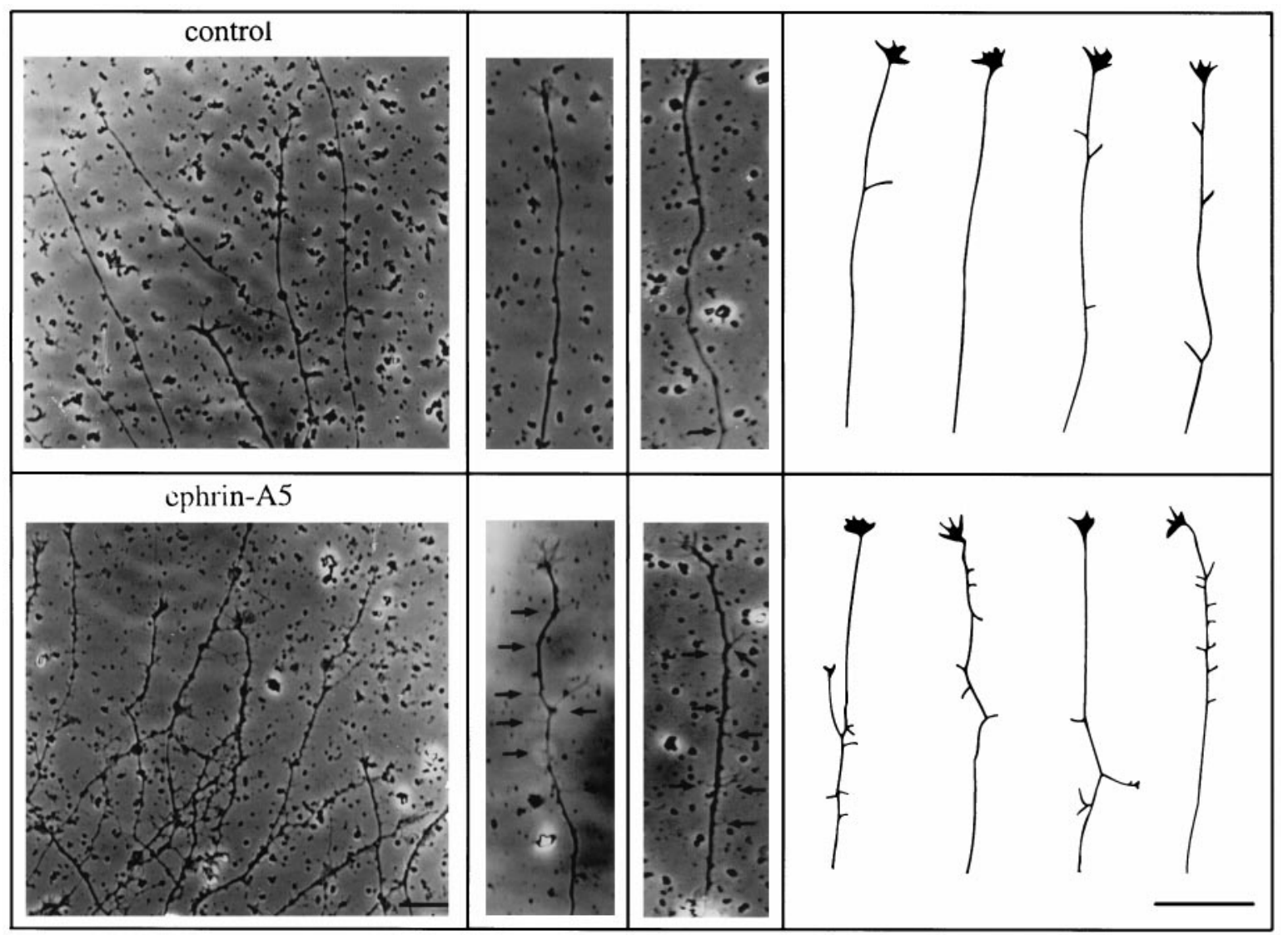

Figure 6. Phase-contrast photomicrographs and camera lucida drawings of individual axons from layer 6 neurons cultured on pure ephrin-A5 and control substrates. Axons form many side branches in the presence of ephrin-A5, whereas only a few branches are emitted under control conditions. Scale bar, $40 \mu \mathrm{m}$.

pressed in cortical layer 4. Thus, ephrin-A5 in layer 4 might promote axonal branching of layer 6 neurons, and one therefore would expect that removal of endogenous ephrin-A5 reduces the branch formation of layer 6 neurons. To examine this issue, cortical explants were cultured on membranes derived from layers 1-4, previously treated with PI-PLC. Analysis of the branch formation revealed that axonal sprouting of layer 6 neurons decreased by $34.7 \%$ on the PI-PLC-treated substrates compared 
Table 3. Axonal branching of layer 6 neurons

\begin{tabular}{lll} 
& & + Soluble ephrin-A5 \\
\hline $\begin{array}{l}\text { Control membranes } \\
\text { Ephrin-A5 mem- } \\
\text { branes }\end{array}$ & $100 \pm 25.8, n=29$ & $85.9 \pm 24.8, n=30 \mathrm{~ns}$ \\
& $222 \pm 33.4, n=33$ & $141.4 \pm 26.5, n=42^{*}$ \\
& Control & + PI-PLC \\
\hline
\end{tabular}

Layers $1-4$ membranes $100 \pm 12.07, n=53 \quad 65.3 \pm 9.6, n=54^{*}$

The explants were grown on membranes from control and ephrin A-5 NIH3T3 cells, in the presence of soluble ephrin-A5 applied to the culture medium. Under these conditions, the increase in axonal branching observed when the explants were cultured on ephrin-A5-containing membranes was significantly reduced. In addition, soluble ephrin-A5 did not promote axonal branching when cortical explants were cultured on control cell membranes. When layer 6 neurons were cultured on cortical membranes prepared from layers 1-4, previously treated with PI-PLC, axonal branching decreased significantly, compared with the control.

${ }^{*} p<0.05$; ns, not significant. $n=$ number of axons examined.

with the control condition (total of 107 axons examined; $p<0.05$ ) (Table 3).

\section{DISCUSSION}

Local circuits in the cerebral cortex are based on the precise arrangement of axon collaterals in distinct cortical layers. We have shown previously that unknown molecular cues confined to individual cortical laminae regulate the elaboration of layerspecific connections in the developing cortex. As discussed below, the laminar expression pattern of ephrin-A5 and its receptor EphA5 together with the highly specific effect of the ligand on distinct populations of growing axons suggest that they contribute to the assembly of local cortical circuits.

\section{Developmental expression of Eph-A5 and ephrin-A5 mRNA}

During corticogenesis, neurons are produced by successive divisions of progenitors cells in the ventricular zone and migrate through the subventricular zone and the intermediate zone toward the cortical plate (Angevine and Sidman, 1961; Rakic, 1972). Our in situ hybridization experiments revealed high levels of EphA5 mRNA expression in the subventricular zone, intermediate zone, and cortical plate at early embryonic stages. From the anatomical data it appears that EphA5 is primarily expressed in postmitotic neurons exiting the ventricular zone, and our in vitro assays indicate that these neurons possess functional receptors for the ephrin-A5 ligand. Previous work provided evidence that the laminar position, transmitter phenotypes, projection patterns, and some area-specific markers of cortical neurons are already specified at very early developmental stages (Horton and Levitt, 1988; McConnell and Kaznowski, 1991; Götz and Bolz, 1994). Because postnatal EphA5 expression is confined to discrete layers, EphA5 might therefore constitute an early molecular marker of the laminar identity of cortical neurons.

At all prenatal stages examined, labeling with ephrin-A5 riboprobes was restricted to the upper part of the cortical plate, and only very low levels of hybridization signals were observed in the ventricular zone. Thus, in contrast to the EphA5 receptor, ephrin-A5 mRNA expression occurs at later developmental stages, after cells have migrated into the cortical plate. Ephrin-A5 could be expressed by cortical neurons and/or glia cells in layer 4 . Previous work reported that cultured astrocytes from young postnatal cortex expressed significantly higher levels of ephrin-A5 RNA compared with cultured neurons from embryonic cortex
(Winslow et al., 1995). Because the postnatal labeling was predominantly confined to layer 4 , this would then suggest that glial cells exhibit distinct laminar identities and contribute to the formation of layer-specific cortical circuits. So far, little is known about the influence of glia on the growth of cortical axons. However, there is evidence from other systems that glial cells influence axonal growth and participate in the guidance of longdistance projections (Bastiani et al., 1986; Snow et al., 1990; Cole and McCabe, 1991; Klambt and Goodman, 1991).

\section{Ephrin-A5 is a repulsive signal for subpopulations of cortical neurons}

Our in vitro experiments reveal a repellent activity of ephrin-A5 on cortical axons. The effects are cell type-specific because axonal responses depended on the laminar position of cortical neurons. On ephrin-A5-containing substrates, the growth rate of layers $2 / 3$ axons was reduced; they often formed thick fascicles, and in the stripe assay they avoided ephrin-A5 membranes. However, ephrin-A5 had no effect on axonal growth, guidance, and fasciculation of layer 6 cells. These findings are consistent with previous studies that reported axon bundle formation and growth cone collapse of dissociated cortical neurons extending on ephrin-A5expressing astrocytes (Winslow et al., 1995; Meima et al., 1997). Evidence for repulsive guidance properties of ephrins came from the work on topographic projections in the retinotectal and hippocamposeptal system. Ephrins in the target regions (tectum, septum) and Eph receptors on the projecting neurons (retinal ganglion cells, hippocampal neurons) have been found to be expressed in opposite gradients that reflect the topographic organization of these connections (Cheng et al., 1995; Drescher et al., 1995; Gao et al., 1996; Nakamoto et al., 1996; Zhang et al., 1996). In the retinotectal system, a repulsive axonal guidance signal (RAGS) (ephrin-A5) induces growth cone collapse of retinal ganglion cell axons, and in stripe assays it acts as a repulsive guidance cue (Drescher et al., 1995). Elf-1 (ephrin-A2) selectively repels temporal retinal axons (Cheng et al., 1995; Nakamoto et al., 1996). In the hippocamposeptal system, ephrin-A2 allows neurite outgrowth from neuronal aggregates prepared from the lateral hippocampus, whereas it reduced the outgrowth of neurons from the medial hippocampus (Gao et al., 1996). Finally, a repellent guidance activity of Nuk ligand on the commissural projections has also been reported. In mice with a mutation introduced into the gene encoding the Eph receptor nuk, the pathway of the posterior tract of the anterior commissure is disrupted; axons extend in a ventral zone that normally would have expressed Nuk receptors (Henkemeyer et al., 1996).

How might the repulsive activity of ephrin-A5 participate in the elaboration of layer-specific local cortical circuits? The efferent axon of a layers $2 / 3$ neuron gives rise to an extensive network of tangentially oriented axon collaterals that run for several millimeters in layers $2 / 3$ and 5 . Later this pattern acquires a clustered distribution allowing individual neurons to selectively integrate information over large parts of the cortex (for review, see Gilbert, 1992). Our in vitro observation that layers $2 / 3$ axons are effectively guided by borders of substrate with and without ephrin-A5, together with the laminar distribution of ephrin-A5, suggests that in vivo the signal might prevent layers $2 / 3$ axons from growing into an inappropriate cortical layer 4. Along with layers $2 / 3$, the second major band of EphA5 receptor expression was detected in layer 5 . These cells form intralaminar projections either to the superficial layers or to layer 6 , but similar to layers $2 / 3$ neurons they only rarely arborize in layer 4 (Gilbert and 
Wiesel, 1979; Martin and Whitteridge, 1984). On the basis of results presented here, one would expect that ephrin-A5 might also exert a repulsive effect on this class of neurons.

\section{Ephrin-A5 promotes axon collateral formation of subpopulations of cortical neurons}

For layer 6 cells we found that ephrin-A5, rather than having an inhibitory or repellent effect, selectively induces axonal sprouting of this class of cortical neurons. This was rather unexpected because this ligand has been originally characterized as a "repulsive axonal guidance signal” (RAGS) by Drescher et al. (1995) in the retinotectal system, and, as mentioned above, all other ligands for Eph receptor tyrosine kinases known today that play a role in neurite elongation and guidance have been reported to exert repulsive effects. However, there is some evidence from published work on the expression of the transcription factors engrailed (en-1 and en-2) in the tectum, which suggests that ephrins might induce collateral branch formation on selected populations of neurons. Several studies demonstrated that engrailed has a graded distribution along the rostrocaudal axes in the tectum that matches the topography along the temporonasal axes of the retinotectal projection (Itasaki and Nakamura, 1992, 1996; Friedman and O’Leary, 1996; Rétaux et al., 1996). Engrailed transcription factors are upstream regulators of ephrin-A5 and ephrin-A2 (Itasaki and Nakamura, 1996; Shigetani et al., 1997). Retroviral misexpression of engrailed in the rostral tectum repelled temporal retinal fibers that normally project to this region. However, nasal retinal fibers that normally project to the caudal tectum exhibited exuberant axonal arborization in patches of rostral tectum where engrailed was expressed. Because ephrins were thought to have exclusive repulsive effects on growing axons, it was suggested that the aberrant arborizations of nasal retinal axons are caused by unknown branching factors farther downstream of the engrailed genes, or alternatively that these arborizations persisted abnormally (Shigetani et al., 1997). Our results directly demonstrate the ability of ephrin-A5 to induce axonal branching in a population of neurons that do not express EphA5 receptors. This effect therefore may be achieved through binding to another Eph family receptor, which would be consistent with the high promiscuity of interactions described for ephrins and their receptors (Gale et al., 1996).

In vivo, ascending axon collaterals of pyramidal neurons in layer 6 neurons branch and expand profusely in ephrin-A5expressing layer 4. We proposed previously that the laminar specificity of these interlaminar projections is achieved by membrane-bound cues restricted to the target layers (Castellani and Bolz, 1997). Our present finding suggests a role of ephrin-A5 in this process of target layer selection. Consistent with this idea, we found that PI-PLC treatment of layer 4 membranes abolished their branch-promoting effect on layer 6 neurons. In addition, recent investigations of ephrin-A5 expression in the developing mouse brain indicate that ephrin-A5 is also present in the thalamus, the main projection target of layer 6 pyramidal neurons (Zhang et al., 1996). This might imply that ephrin-A5 also contributes to the invasion and arborization of layer 6 axons in their distant projection target.

In conclusion, our results indicate that ephrin-A5 has selective and cell type-specific effects on cortical axons. As described previously for other populations of neurons, it acts selectively as a "repulsive axonal guidance signal" for cortical neurons destined for layers $2 / 3$, without affecting axonal arborizations. In contrast, for neurons destined for layer 6 , ephrin-A5 acts as a "branch- promoting" signal, but it has no effect on axonal guidance for this class of neurons. These contrasting effects of ephrin-A5 on different populations of cortical cells together with its laminar distribution in the developing cortex are consistent with the patterns of intrinsic connections formed by these neurons. Thus, ephrin-A5 functions in alternative ways and thereby serves as one of the signals for assembling the intricate network of cortical circuits.

\section{REFERENCES}

Angevine JB, Sidman RL (1961) Autoradiographic study of cell migration during histogenesis of cerebral cortex in the mouse. Nature 192:766-768.

Auladell C, Martinez A, Alcantara S, Supèr H, Soriano E (1995) Migrating neurons in the developing cerebral cortex of the mouse send callosal axons. Neuroscience 64:1091-1103.

Bastiani MJ, du Lac S, Goodman CS (1986) Guidance of neuronal growth cones in the grasshopper embryo. I. Recognition of a specific axonal pathway by the pCC neuron. J Neurosci 6:3518-3531.

Bayer SA, Altman J (1991) Neocortical development. New York: Raven.

Berry M, Eayrs JT (1963) Histogenesis of the cerebral cortex. Nature 197:984-985.

Berry M, Rogers AW (1965) The migration of neuroblasts in the developing cerebral cortex. J Anat 99:691-709.

Burkhalter A (1989) Intrinsic connections of rat primary visual cortex: laminar organization of axonal projections. J Comp Neurol 279:171-186.

Callaway EM, Katz LC (1990) Emergence and refinement of clustered horizontal connections in cat striate cortex. J Neurosci 10:1134-1153.

Callaway EM, Lieber JL (1996) Development of axonal arbors of layer 6 pyramidal neurons in ferret primary visual cortex. J Comp Neurol 376:295-305.

Castellani V, Bolz J (1997) Membrane-associated molecules regulate the formation of layer-specific cortical circuits. Proc Natl Acad Sci USA 94:7030-7035.

Cheng HJ, Nakamoto M, Bergemann AD, Flanagan JG (1995) Complementary gradients in expression and binding of ELF-1 and MEK4 in development of the topographic retinotectal projection map. Cell 82:371-381.

Cole GJ, McCabe CF (1991) Identification of a developmentally regulated keratan sulfate proteoglycan that inhibits cell adhesion and neurite outgrowth. Neuron 7:1007-1018.

Davis S, Gale NW, Aldrich TH, Maisonpierre TC, Lhotak V, Pawson T, Goldfarb M, Yancopoulos GD (1994) Ligands for EPH-related receptor tyrosine kinases that require membrane attachment or clustering for activity. Science 266:816-819.

Drescher U, Kremoser C, Handwerker C, Löschinger J, Noda M, Bonhoeffer F (1995) In vitro guidance of retinal ganglion cell axons by RAGS, a $25 \mathrm{kDa}$ tectal protein related to ligands for Eph receptor tyrosine kinases. Cell 82:359-370.

Eph Nomenclature Committee (1997) Unified nomenclature for Eph family receptors and their ligands, the ephrins. Cell 90:403-404.

Fisken RA, Garey LJ, Powell TPS (1975) The intrinsic, association and commissural connections of area 17 of the visual cortex. Philos Trans R Soc Lond B Biol Sci 272:487-536.

Fitzpatrick D (1996) The functional organization of local circuits in visual cortex: insights from the study of tree shrew striate cortex. Cereb Cortex 6:329-341.

Friedman GC, O'Leary DDM (1996) Retroviral misexpression of engrailed genes in the chick optic tectum perturbs the topographic targeting of retinal axons. J Neurosci 16:5498-5509.

Gale NW, Holland SJ, Valenzuela DM, Flenniken A, Pan L, Ryan TE, Henkemeyer M, Strebhardt K, Hirai H, Wilkinson DG, Pawson T, Davis S, Yancopoulos GD (1996) Eph receptors and ligands comprise two major specificity subclasses and are reciprocally compartmentalized during embryogenesis. Neuron 17:9-19.

Gao PP, Zhang JH, Yokoyama M, Racey B, Dreyfus CF, Black IB, Zhou R (1996) Regulation of topographic projection in the brain: Elf- 1 in the hippocamposeptal system. Proc Natl Acad Sci USA 93:11161-11166.

Gilbert CD (1992) Horizontal integration and cortical dynamics. Neuron 9:1-13. 
Gilbert CD, Wiesel TN (1979) Morphology and intracortical projections of functionally characterised neurones in the cat visual cortex. Nature 280:120-125.

Gilbert CD, Wiesel TN (1983) Clustered intrinsic connections in cat visual cortex. J Neurosci 3:1116-1133.

Gilbert CD, Wiesel TN (1989) Columnar specificity of intrinsic horizontal and corticocortical connections in cat visual cortex. J Neurosci 9:2432-2442.

Götz M, Bolz J (1994) Differentiation of transmitter phenotypes in rat cerebral cortex. Eur J Neurosci 6:18-32.

Götz M, Novak N, Bastmeyer M, Bolz J (1992) Membrane bound molecules in rat cerebral cortex regulate thalamic innervation. Development 116:507-519.

Henkemeyer M, Orioli D, Henderson JT, Saxton TM, Roder J, Pawson T, Klein R (1996) Nuk controls pathfinding of commissural axons in the mammalian central nervous system. Cell 86:35-46.

Horton HL, Levitt P (1988) A unique membrane protein is expressed on early developing limbic systems axons and cortical targets. J Neurosci 8:4653-4661.

Hübener M, Schwarz C, Bolz J (1990) Morphological types of projection neurons in layer 5 of cat visual cortex. J Comp Neurol 301:655-674.

Itasaki N, Nakamura H (1992) Rostrocaudal polarity of the tectum in birds: correlation of en gradients and topographic order in retinotectal projection. Neuron 8:787-798.

Itasaki N, Nakamura H (1996) A role for gradient en expression in positional specification on the optic tectum. Neuron 16:55-62.

Kageyama GH, Robertson RT (1993) Development of geniculocortical projections to visual cortex in rat: evidence for early ingrowth and synaptogenesis. J Comp Neurol 335:123-148.

Katz LC (1991) Specificity in the development of vertical connections in cat striate cortex. Eur J Neurosci 3:1-9.

Katz LC, Callaway EM (1992) Development of local circuits in mammalian visual cortex. Annu Rev Neurosci 15:31-56.

Kennedy TE, Serafini T, De la Torre JR, Tessier-Lavigne M (1994) Netrins are diff usible chemotropic factors for commissural axons in the embryonic spinal cord. Cell 78:425-435.

Klämbt C, Goodman CS (1991) The diversity and pattern of glia during axon pathway formation in the Drosophila embryo. Glia 4:205-213.

Lillian L (1996) Changes in retinal cell fate induced by overexpression of EGF receptor. Nature 377:158-162.

Löwel S, Singer W (1992) Selection of intrinsic horizontal connections in the visual cortex by correlated neuronal activity. Science 255:209-212.

Luhmann HJ, Greuel JM, Singer W (1990) Horizontal interactions in cat striate cortex: III. Ectopic receptive fields and transient exuberance of tangential interactions. Eur J Neurosci 2:369-377.

Lund JS, Boothe RG (1975) Interlaminar connections and pyramidal neuron organisation in the visual cortex, area 17, of the macaque monkey. J Comp Neurol 159:305-334.

Lund JS, Boothe RG, Lund RD (1977) Development of neurons in the visual cortex of the monkey (Macaca memestrina): a Golgi study from fetal day 127 to postnatal maturity. J Comp Neurol 176:149-188.

Luo Y, Raible D, Raper JA (1993) Collapsin: a protein in brain that induces the collapse and paralysis of neuronal growth cones. Cell 75:217-227.

Luskin MB, Shatz CJ (1985) Neurogenesis of the cat's primary visual cortex. J Comp Neurol 242:611-631.

Malach R, Amir Y, Harel M, Grinvald A (1993) Relationship between intrinsic connections and functional architecture revealed by optical imaging and in vivo targeted biocytin injections in primate striate cortex. Proc Natl Acad Sci USA 90:10469-10473.

Martin KAC, Whitteridge D (1984) Form, function and intracortical projections of spiny neurons in the striate cortex of the cat. J Physiol (Lond) 353:463-504.

McConnell SK, Kaznowski CE (1991) Cell cycle dependence of laminar determination in developing neocortex. Science 254:282-285.

Meima L, Kljavin IJ, Moran P, Shih A, Winslow JW, Caras IW (1997) $\mathrm{AL}$-1-induced growth cone collapse of rat cortical neurons is correlated with REK7 expression and rearrangement of the actin cytoskeleton. Eur J Neurosci 9:177-188.

Messersmith EK, Leonrdo ED, Shatz CJ, Tessier-Lavigne M, Goodman CS, Kolodkin AL (1995) Semaphorin III can function as a selective chemorepellent to pattern sensory projections in the spinal cord. Neuron 14:949-959.

Meyer G, Ferres-Torres R (1984) Postnatal maturation of nonpyramidal neurons in the visual cortex of the cat. J Comp Neurol 228:226-244.

Miller MW (1988) Development of projection and local circuit neurons in neocortex. In: Cerebral cortex, Vol 7: Development and maturation of cerebral cortex (Peters A, EG Jones, eds), pp 133-175. New York: Plenum.

Miller MW, Peters A (1981) Maturation of rat visual cortex. II. A combined Golgi-electron microscopic study of pyramidal neurons. J Comp Neurol 203:555-573.

Nakamoto M, Cheng HJ, Friedman GC, McLaughlin T, Hansen MJ, Yoon CH, O'Leary DDM, Flanagan JG (1996) Topographically specific effects of ELF-1 on retinal axon guidance in vitro and retinal axon mapping in vivo. Cell 86:755-766.

Püschel AW, Adams RH, Betz H (1995) Murine semaphorins D/collapsin is a member of a diverse gene family and creates domains inhibitory for axonal extension. Neuron 14:941-948.

Rakic P (1972) Mode of cell migration to the superficial layers of fetal monkey neocortex. J Comp Neurol 145:61-84.

Rétaux S, McNeill L, Harris WA (1996) Engrailed, retinotectal targeting, and axonal patterning in the midbrain during Xenopus development: an antisense study. Neuron 16:63-75.

Rockland KS, Lund JS, Humphrey AL (1982) Anatomical banding of intrinsic connections in striate cortex of tree shrews (Tupaia glis). J Comp Neurol 209:41-58.

Schwartz ML, Rakic P, Goldman-Rakic PS (1991) Early phenotype expression of cortical neurons: evidence that a subclass of migrating neurons have callosal axons. Proc Natl Acad Sci USA 88:1354-1358.

Schwarz C, Bolz J (1991) Functional specificity of a long-range horizontal connection in cat visual cortex: a cross-correlation study. J Neurosci 11:2995-3007.

Serafini T, Kennedy TE, Galko MJ, Mirzayan C, Jessell TM, TessierLavigne M (1994) The netrins define a family of axon outgrowthpromoting proteins homologous to C. elegans UNC-6. Cell 78:409-424.

Shigetani Y, Funahashi J-I, Nakamura H (1997) En-2 regulates the expression of the ligands for Eph type tyrosine kinases in chick embryonic tectum. Neurosci Res 27:211-217.

Shoukimas GM, Hinds JW (1978) The development of the cerebral cortex in the embryonic mouse: an electron microscopic serial section analysis. J Comp Neurol 179:795-830.

Snow DM, Steindler DA, Silver J (1990) Molecular and cellular characterization of the glial roof plate of the spinal cord and optic tectum: a possible role for a proteoglycan of the development of an axon barrier. Dev Biol 138:359-376.

Ts'o DY, Gilbert CD, Wiesel TN (1986) Relationships between horizontal interactions and functional architecture in cat striate cortex as revealed by cross-correlation analysis. J Neurosci 6:1160-1170.

Walter J, Kern-Veits B, Huf J, Stolze B, Bonhoeffer F (1987) Recognition of position-specific properties of tectal cell membranes by retinal axons in vitro. Development 101:685-696.

Winslow JW, Moran P, Valverde J, Shih A, Yuan JQ, Wong SC, Tsai SP, Goddard A, Henzel WJ, Hefti F, Beck KD, Caras IW (1995) Cloning of AL-1, a ligand for an Eph-related tyrosine kinase receptor involved in axon bundle formation. Neuron 14:973-981.

Zhang JH, Cerretti DP, Yu T, Flanagan JG, Zhou RP (1996) Detection of ligands in regions anatomically connected to neurons expressing the eph receptor Bsk: potential roles in neuron-target interaction. J Neurosci 16:7182-7192.

Zhang J-H, Pimenta AF, Levitt P, Zhou R (1997) Dynamic expression suggests multiple roles of the eph family receptor brain-specific kinase (Bsk) during mouse neurogenesis. Mol Brain Res 47:202-214.

Zhou R, Copeland TD, Kromer LF, Schulz NT (1994) Isolation and characterization of Bsk, a growth factor receptor-like kinase associated with the limbic system. J Neurosci Res 37:129-143. 